\title{
THE FORTS OF THE LIESBEECK FRONTIER
}

\section{Dan Sleigh}

Castle Military Museum, Cape Town: 1996

\section{5 pages}

illustrated, maps

ISBN 0-620-20775-2

R27-50

This is the second of a new, attractive series of booklets dealing with Cape military history and published by the Castle Military Museum, Cape Town. Published in A5 landscape format, this series has tremendous potential as an educator: they are informative, reasonably cheap, and relatively accessible in terms of language.

The first number in the series, T.D. Potgieter's The First British Occupation of the Cape (1995), set a standard of which the second number falls short. Dan Sleigh's Forts of the Liesbeeck Frontier, although a précis of a master's dissertation, ${ }^{1}$ does not have the same pithiness and depth. It lacks the collection of selected documents which gave added substance to The First British Occupation: a technique well-used by the "Seminar Studies in History" series. Document work is now in vogue, allowing analysis and assessment in combination with a text; and the departure of the Castle Military Museum series from this pattern, is truly a pity. The decision should be reviewed.

Furthermore, it is unfortunate that more attention was not paid to technical care. The book not only lacks a conclusion but also appears to have no introduction; and, furthermore, the "World Map" on page six has no function. It is, however, furnished with a useful glossary and an index; although most surprisingly the latter contains no references for a number of key subject areas mentioned in the actual text. The Dutch-Khoikhoi wars (for example, on page 26 ) is a case in point.

But perhaps the greatest hiatus is the general lack of information regarding the Khoikhoi, against whose activities the forts were designed. It is true that the Khoikhoi left no written record but it is equally untrue that all that is known about them was written by Europeans (page 15). Two valuable Khoikhoi-generated sources include artifacts and rock art, the latter normally depicting hunting and battle scenes. These potentially-valuable sources are not mentioned let alone evaluated.

The short piece on the "Aborigines of the Cape" contains little detail on the weapons or tactics used by the Khoikhoi during the sixteenth and seventeenth centuries. The information is generally vague. Yes, Khoikhoi "oxen were trained for war" (page 17). But, thanks to the labours of particularly Richard Elphick, much more is known. By driving their cattle

D. Sleigh, Die buiteposte van die VOC aan die grens van die Kaapse nedersetting, 1652-1707, submitted at the University of Stellenbosch in 1982 
him it was indeed over in September 1917 when he fell ill and was hospitalized.

His letters chronicle his daily life, first as a private and later as an officer. He describes those aspects of war which are mostly neglected in the official documents: the soldiers' diet and their living conditions; the excitement of receiving mail and parcels with treats from home; the way they spent their leisure time; their frustations and longings; the fact that the ordinary soldier often had very little information on the progress of the war ("You've no idea how difficult it is to get news here where history is in the making."); the fellowship among the men and the sadness when losing a comrade in battle.

Wade wrote about the happenings of the war in a rather matter of fact way. Obviously, being exposed to the horrors of war and the ever present possibility of death, blunted his sensitivity. To what extent is evident from his description of how, during the Battle of the Somme, he and a number of his fellow men collected souvenirs from the bodies of dead German soldiers - adding that the "dried out corpses......are too old and weathered to be offensive". Apparently he did not consider this action as out of the ordinary; this is underscored by the fact that directly following his description of this macabre outing, he tells of the parcel containing cakes, cheese and sweets he received.

The military section of the material forms the main part of the publication and therefore, although the part on the first few months of his stay in Tanganyika as a mining engineer in government service makes interesting reading, it does not fit in with the rest of the book. These entries could well have been left out.

Because Peace, War and Afterwards consists of letters, the editor added a number of notes to the text to clarify certain facts. However, these notes are often not enough to put the reader in the picture properly or to provide the necessary background. For example, a few biographical details on Wade (age, occupation, place of residence before leaving South Africa) should have been given at the beginning of the book; also lacking is an annotation filling in the time and events between Wade's arrival back in South Africa and his departure for East Africa. It should also be noted that the reader who is not knowledgeable about the First World War will experience difficulty following the progress of the conflict. Nonetheless, Peace, War and Afterwards is a worthy publication which provides insight into the lesser known facets of the war.

Louise Jooste Documentation Service Directorate, SANDF, Pretoria 
between themselves and an enemy, the Khoikhoi used their cattle as something of a moving rampart. This protective buffer, not only shielded the Khoikhoi but was also used offensively to confuse the enemy and disrupt the enemy battle order.

Likewise, the meagre references to Khoikhoi weapons might easily have been expanded. The Khoikhoi used their hunting weapons for war; and this meant that there was some similarity between their hunting methods and their battle tactics. The writer leaves a number of important questions, unanswered: how did Khoikhoi tactics fare against the Liesbeeck forts? We note on page 29 , that the wooden fence withstood a drive of cattle; but what of the forts themselves?

We know too that the Khoikhoi generally avoided close combat, maximizing their long-range weapons (bow-and-arrow and throwing spear). Did the Dutch forts force a change in Khoikhoi tactics? The forts were clearly not a foci of Dutch-Khoikhoi confrontation, as they could be too easily by-passed. Thus it would appear that, as was the case of the blockhouses of the Second Anglo-Boer War, the value of the forts lay in observation and as strong-points for the launch of a counterattack in the sector in which the fence was breached. Yet this matter is not adequately explained.

Nonetheless, Sleigh has undoubtedly made a commendable contribution to the Castle Military Museum series. He offers inter alia insight into the vexing dilemma which faced by the early-Dutch administrators at the Cape: the provision of adequate security arrangements for the small settlement, the maintenance and development of which were constantly confounded by a low defence budget. The dilemma is ominously familiar!

I.J. van der Waag Department of Military History, Faculty of Military Science, University of Stellenbosch 